\title{
The crustal deformation of the Ilan Plain acted as a westernmost extension of the Okinawa Trough
}

\author{
Chin-Shyong Hou ${ }^{\mathrm{a}, \mathrm{b}}$, Jyr-Ching Hu ${ }^{\mathrm{b}, *}$, Kuo-En Ching ${ }^{\mathrm{c}}$, Yue-Gau Chen ${ }^{\mathrm{b}}$, Chien-Liang Chen ${ }^{\mathrm{a}}$, \\ Li-Wei Cheng ${ }^{a}$, Chao-Lung Tang ${ }^{b}$, Shin-Hua Huang ${ }^{b}$, Ching-Hua Lo ${ }^{b}$ \\ ${ }^{a}$ Central Geological Survey, MOEA, P.O. Box 968, Taipei, Taiwan \\ ${ }^{\mathrm{b}}$ Department of Geosciences, National Taiwan University, Taipei, Taiwan \\ ${ }^{\mathrm{c}}$ Department of Geosciences, National Taiwan University, Taiwan
}

Available online 22 November 2007

\begin{abstract}
We analyze the current deformation in Ilan Plain of northeastern Taiwan considered as the western extension of Okinawa Trough based on 34 geodetic sites observed between 2002 and 2006. The station velocities are between $1.9 \mathrm{~mm} / \mathrm{yr}$ and $43.0 \mathrm{~mm} / \mathrm{yr}$ in a direction between $38{ }^{\circ}$ and $143^{\circ}$ relative to stable continent margin of Eurasian plate. This largest velocity is moving southeastward $\left(143^{\circ}\right)$ at a rate of $\sim 43 \mathrm{~mm} / \mathrm{yr}$ was enhanced by a seismic doublet that occurred on March 6, 2005. The station velocities at the northern margin of Ilan Plain are insignificant with a magnitude of $\sim 1.9 \mathrm{~mm} / \mathrm{yr}$ to $\sim 7.5 \mathrm{~mm} / \mathrm{yr}$. On the contrary, the station velocities increase approximately southward along the southern margin of Ilan Plain. The stations are moving roughly E-W with a magnitude of $\sim 5.8 \mathrm{~mm} / \mathrm{yr}$ to $\sim 21.8 \mathrm{~mm} / \mathrm{yr}$. Further southward, the station velocities increase to a value of $\sim 43.0 \mathrm{~mm} / \mathrm{yr}$ in a direction of $143^{\circ}$. The most prominent feature of the strain distribution patterns in Ilan Plain are the remarkable extensional strain rates observed in central and southern flank of the Ilan Plain. The largest extensional rate is found (2.66 $\mu$ strain/yr in $\left.147^{\circ}\right)$ with a shortening rate in the perpendicular direction $\left(1.28 \mu \mathrm{strain} / \mathrm{yr}\right.$ in $\left.57^{\circ}\right)$, indicating transtensional deformation mode. In the northeastern flank of Ilan Plain, insignificant or minor deformations are observed. Overall the extensional rates in this area clearly increase from north to south. The extension directions in study area mostly trend E-W to NW-SE directions. Using the velocity field of 34 GPS stations and its strain rate filed, we suggest the lateral extrusion process towards mechanically weak domain adjacent Ryukyu subduction zone. The lateral extrusion is facilitated by the opening of the Okinawa Trough. We conclude that the northeast Taiwan is subjected to both the compressional force exerted by the indentation of Philippine Sea plate and the tensile force induced by trench retreat related to the suction force at the Ryukyu trench. Due to the interaction of two forces, the stress regime rapidly changes from pure compression in the Taiwan collision belt to transtension near Ilan Plain and its offshore area.
\end{abstract}

(C) 2007 Elsevier B.V. All rights reserved.

Keywords: GPS; Okinawa Trough; Crustal deformation; Taiwan

\section{Introduction}

The Global Positioning System (GPS) is a powerful tool to better understand plate kinematics and crustal deformation (Dixon, 1991; Segall and Davis, 1997). In order to characterize the kinematics of deformation along the convergent plate boundary of Taiwan, the island-wide and local GPS Network

\footnotetext{
* Corresponding author. Fax: +8862 23636095

E-mail address: jchu@ntu.edu.tw (J.-C.Hu).
}

was established since 1990 (Yu et al., 1997; Yu and Kuo, 2001). These GPS data provided the amplitude and orientation of tectonic motion across the plate boundary of Taiwan. To better reconstruct the ongoing deformation in different tectonic domains, the dense network was established by Central Geological Survey since 1996 in the Taiwan area, it thus became possible to monitor the regional deformation along and around major active structures in different tectonic regimes. In addition, the crustal deformation in Ryukyu arc estimated from GPS data provided the geodynamic constrain of tectonic implication (Nakamura, 2004; Nishimura et al., 2004). 
The southeast-facing Ryukyu arc-and-trench system extends from southern Kyushu to east of Taiwan. This subduction zone is associated with the back-arc spreading in the Okinawa Trough, which ends in the Ilan Plain of northeastern Taiwan (Fig. 2), where active transtension and transpression are occurring ( $\mathrm{Lu}$ et al., 1995; Hu et al., 1996, 1997, 2002). In order to address the consistency between stress pattern and active deformation, several numerical experiments considering strain-stress relationships were carried out (e.g., Hu et al., 1996, 2002). These experiments aimed at evaluating the general compatibility between the kinematic boundary conditions, the geological structure, rheology and paleostress patterns.

In this paper, we aim at characterizing the crustal deformation in Ilan Plain of northern Taiwan located in a transition zone of collision and surrounding subduction. From the tectonic point of view, the rapid change of tectonic behavior from oblique subduction to collision in the westernmost Ryukyu-
Taiwan region is intriguing due to the complex seismogenic structures in this transition zone. The relationship between seismogenic structures showing different patterns of crustal strain provides fundamental constraints on the accommodation of deformation along the transition of the subduction-collision process. We thus use deformation data from GPS measurements from 2002 to 2006 to better quantify the rate, style and distribution deformation currently taking place along the complex oblique subduction to collision boundary of northern Taiwan.

\section{Tectonic setting}

The island of Taiwan is located along a segment of the convergent boundary between the Philippine Sea plate and Eurasia, where collision and subduction processes occur (Fig. 1). The presence of a Wadati-Benioff zone is clearly indicated

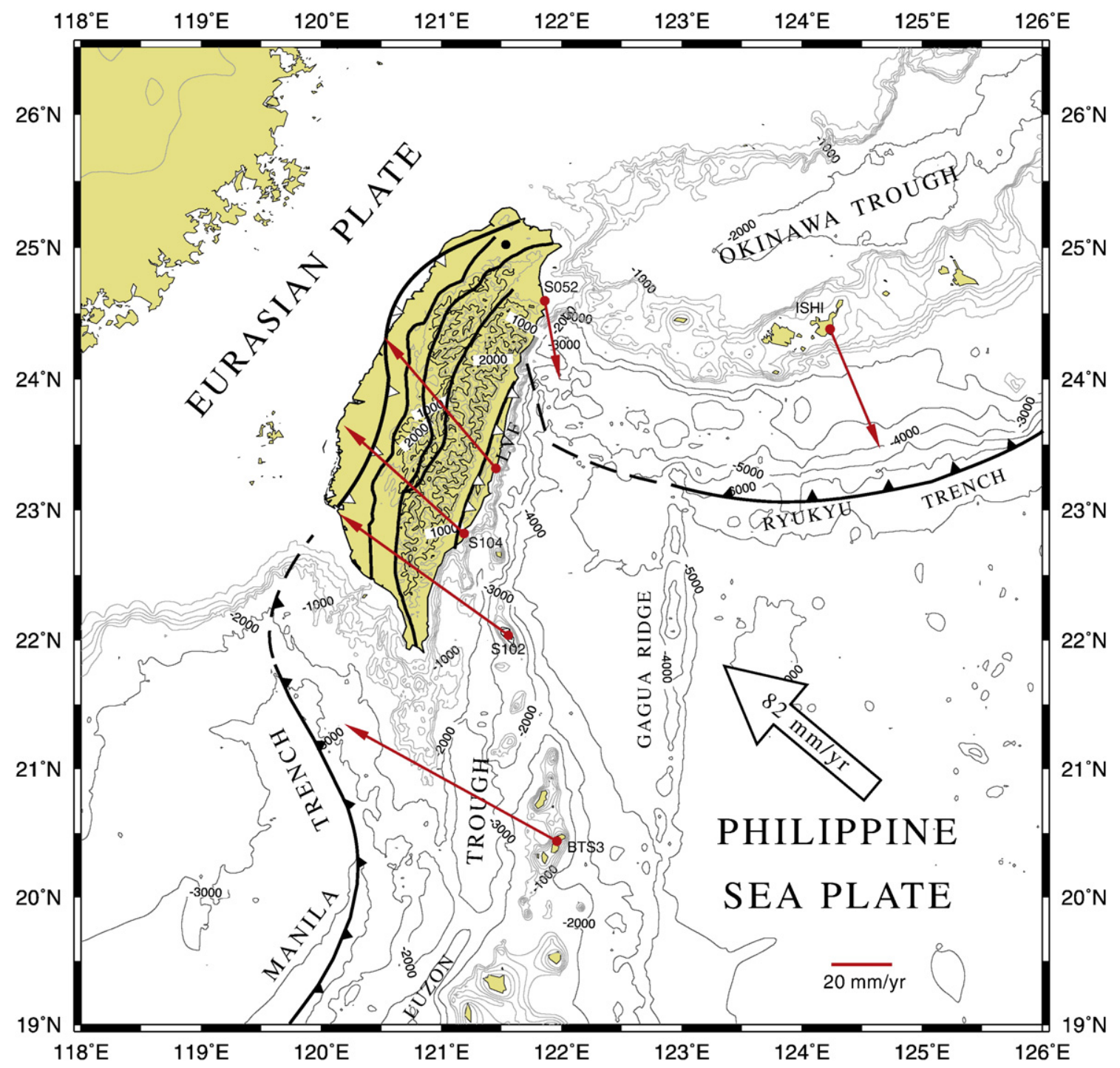

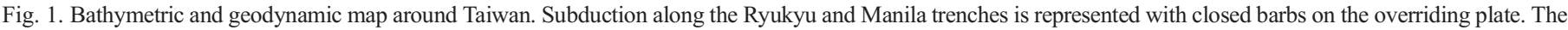

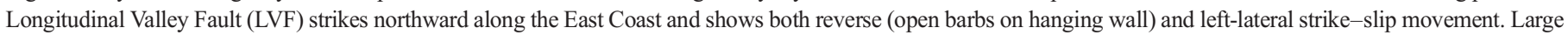

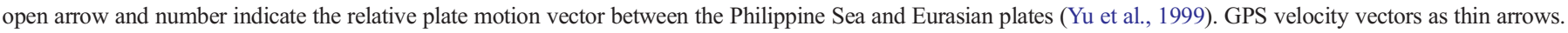


by seismicity northeast of Taiwan, where the Philippine Sea plate is being subducted northward along the Ryukyu trench (Tsai, 1986; Kao et al., 1998; Lallemand et al., 1999). In contrast, south of Taiwan, the Eurasian plate subducts southeastward beneath the Philippine Sea plate along the Manila trench (Kao and Jian, 2001; Malavieille et al., 2002). The Taiwan collision zone thus marks a segment of plate boundary where subduction undergoes a reversal polarity. Taiwan is the place where the Luzon arc initially collided with the Eurasian continent about $5 \mathrm{Ma}$ ago (Ho, 1986; Angelier, 1990; Teng, 1990, 1996). The fold-and-thrust belt of Taiwan advanced northwestward, while the orogen growth was propagating southwestward along the passive continent margin of the Eurasian plate (Suppe, 1984).

A characteristic feature of the Taiwan mountain belt is the major change in the general structural trends between central Taiwan and northern Taiwan. On average, the mountain ranges in central Taiwan trend NNE-SSW south of $24.5^{\circ} \mathrm{N}$, whereas in northeastern Taiwan they trend ENE-WSW (Suppe, 1984; Angelier et al., 1990). The existence of major change in structural trends of about $55^{\circ}$ between 24The existence of major change in structural trenN and $25^{\circ} \mathrm{N}$ (Fig. 2) has been interpreted to the result of subduction flipping and opening of the Okinawa Trough (Suppe, 1984). In addition, northeast Taiwan has undergone post-collisional processes and has been incorporated in the southern Ryukyu arc system. Evidence for this late evolution is provided by the presence of Quaternary extensional structures (Lee and Wang, 1988; Lu et al., 1995) and extensional earthquake focal mechanisms (Tsai, 1986; Yeh et al., 1991; Kao et al., 1998). All of these features indicate that the polarity of subduction has flipped in northern Taiwan; accordingly, the compressional tectonism that resulted in the growth of the Taiwan orogen has been replaced by the extensional tectonism of the Okinawa Trough (Suppe, 1984; Lee and Wang, 1988; Teng, 1996).

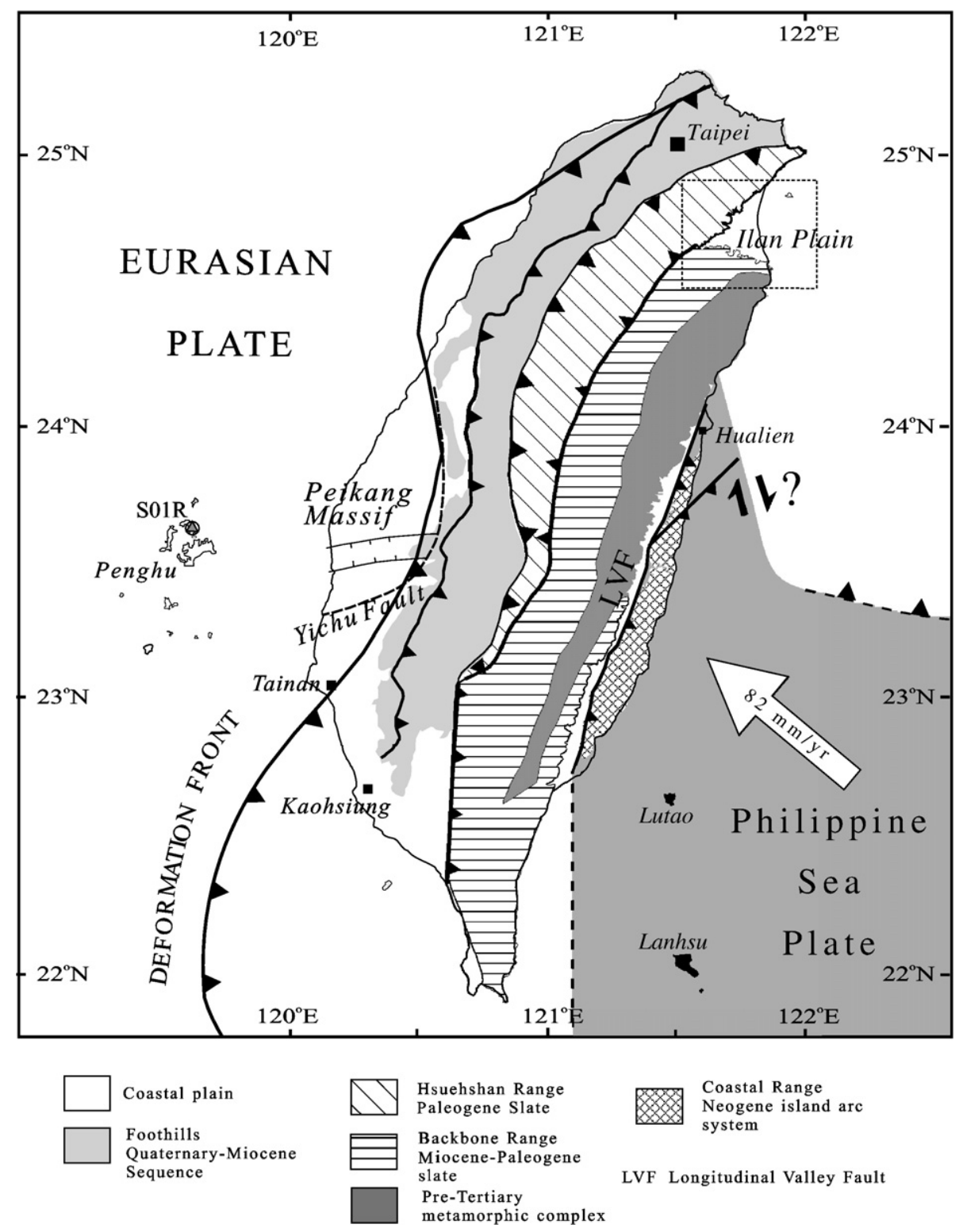

Fig. 2. Tectonic framework and main structural units in Taiwan. Main tectonic units (Ho, 1986). Major thrust faults with triangles on the upthrust side. 
Recent studies of fault slip data sets (Lu et al., 1995) and focal mechanisms of earthquakes (Yeh et al., 1991) have shown that $\mathrm{N}-\mathrm{S}$ and $\mathrm{E}-\mathrm{W}$ extensional trends are common throughout northernmost Taiwan and the Ilan Plain area. According to most analyses, $\mathrm{N}-\mathrm{S}$ extension dominates near the western tip of the Okinawa Trough (Ilan Plain and adjacent offshore areas), whereas E-W extension prevails in northernmost Taiwan (Taipei basin and the Tatung volcano field). To the east, the $\mathrm{N}-\mathrm{S}$ extension is widespread in the Ryukyu arc and corresponds to back-arc spreading activity of the Okinawa Trough. The Okinawa Trough shows various extensional features including grabens and en-échelon structures identified from regional bathymetry and seismic reflection profiles (Sato et al., 1994; Sibuet et al., 1987, 1998), and earthquake focal mechanisms showing extensional faulting (Kao and Chen, 1991). Near the Ilan Plain, the background seismicity demonstrates two significant seismic zone trending NE-SW with a normal type earthquake (Fig. 3). In the northern tip of Central Range near the southern flank of Ilan Plain, the strike-slip type earthquakes are dominant (Fig. 3).

Several numerical experiments carried out (Hu et al., 1996, 2002) successfully to characterize the regional transtensional and transpressional deformation occurring in northern Taiwan (Fig. 4). The Okinawa Trough is the back-arc basin of the Ryukyu subduction system (Fig. 1). The westward propagation of the opening of the Okinawa Trough splits the mountainous backbone which resulted in triangular Ilan Plain (Fig. 1). On the northwestern flank of the Ilan Plain is the Hsüeshan Range, consisting of late Eocene to early Miocene strata deposited probably in a submarine half-graben of the Asian continental shelf (Teng, 1992). On the southern flank of the plain is the

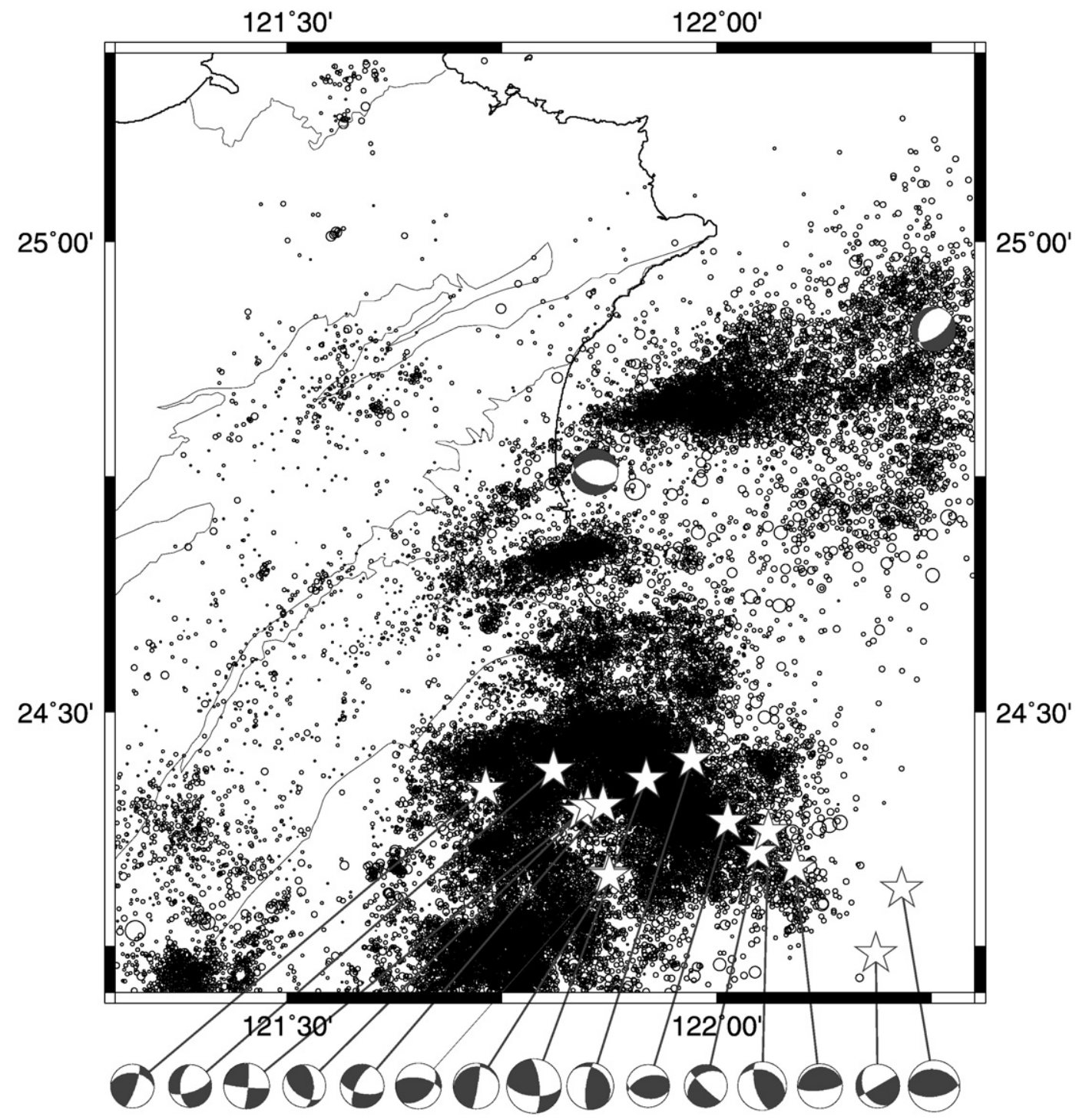

Fig. 3. Seismicities of $M_{\mathrm{L}}>3$ in northeastern Taiwan from 1994 to 2000 based on the Catalog of Central Weather Bureau. The focal mechanisms of magnitude 5.0 to 6.0 are shown. 

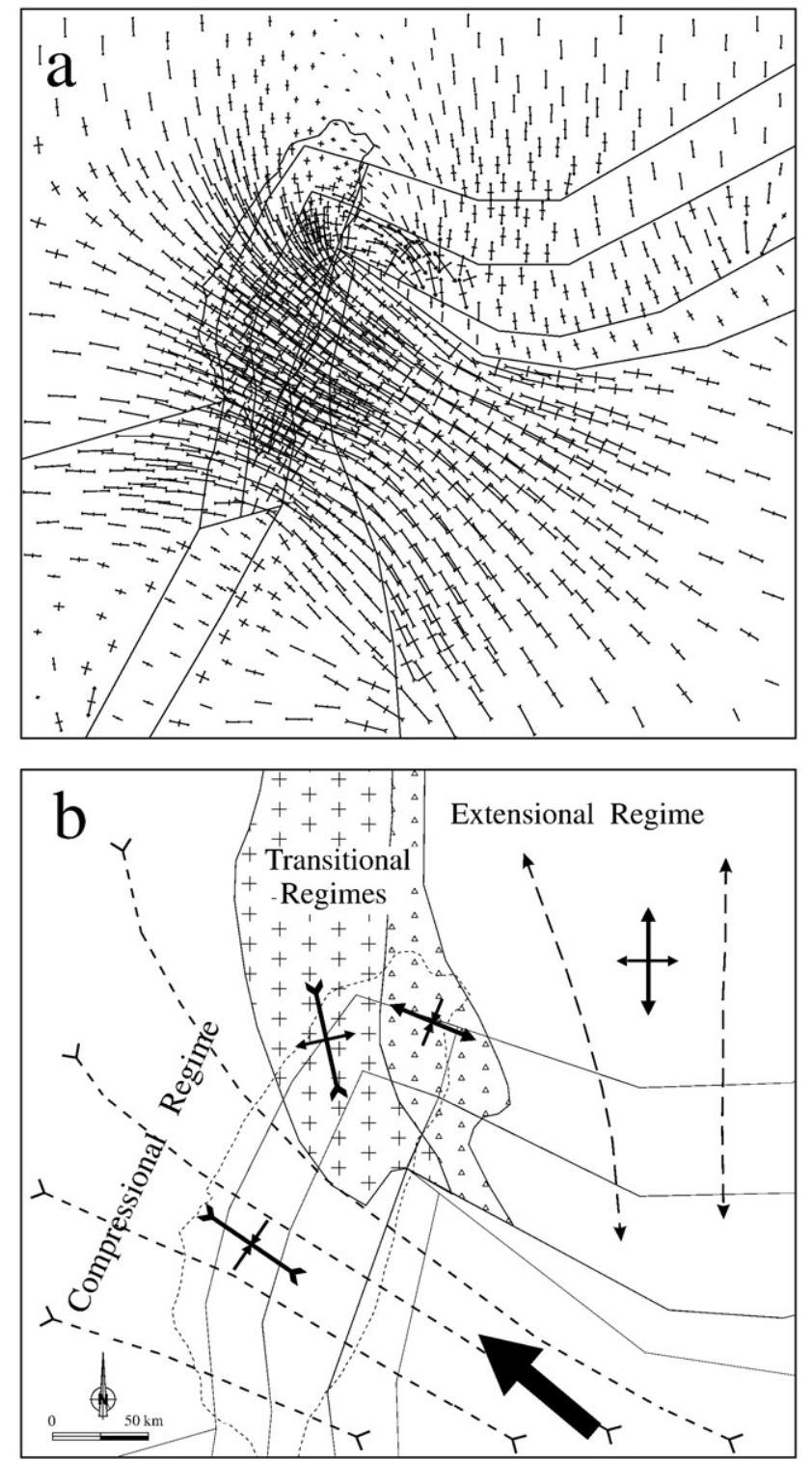

Fig. 4. (a) Stress distribution calculated in the convergence-trench retreat elastoplastic model (Hu et al., 2002). Principal stresses in the horizontal plane, shown as small couples of arrows. Pairs of convergent arrows represent maximum compressive stress. Pairs of divergent arrows represent minimum extensional stress. (b) Resulting tectonic regimes and the trajectories of $\sigma_{1}$, based on model shown in Fig. 3a.

northern tip of the Central Range, a complex of late Paleozoic to late Mesozoic greenschist-facies metamorphic rocks and Miocene slates. The stratigraphic evidence demonstrates that post-collisional collapse of northeastern Taiwan has occurred in just the past million years (Teng, 1996; Teng et al., 2000). Paleostress analyses also reveal a change from contraction to extension in the stress field of northern Taiwan (Lee and Wang, 1988).

\section{GPS results}

In order to analyze the current crustal deformation in the Ilan area, the 'Ilan GPS Network' was established in 2002 by the
Central Geological Survey, Ministry of Economic Affairs (Fig. 5). It is composed of 34 annually surveyed stations. During the period from December 2002 to December 2006, the stations of the network were surveyed 4 times with dual-frequency geodetic GPS receivers. The changes in baseline components derived from these repeated and continuous GPS measurements provided accurate estimates of the relative velocities of GPS stations in study area (Figs. 5 and 6). In each survey, 4-8 stations were observed simultaneously with dual-frequency geodetic receivers (Trimble 4000SSE, Trimble 4000Ssi, Trimble 4700, Trimble 4800, Trimble 5700). The antenna types include TRM22020.00+ GP, TRM41249.00, TRM33429.20+GP, TRM33429.20+GP, TRM33429.00+GP, TRM32119.02 and TRM14532.00. Moreover, each station was usually active during more than two sessions, each session being composed of 6-14 h of GPS data acquisition from all available satellites rising higher than a $15^{\circ}$ elevation angle. Although the duration of the observed session will affect the geometric bias, at least $6 \mathrm{~h}$ of observation would reduce the influence of geometric bias based on the observation of two stations in eastern Taiwan (information from L.-C. Kuo). The sampling interval was $15 \mathrm{~s}$. Daily solutions were computed for continuous GPS data. The ionosphere-free linear combination of observations at the L1 and L2 frequencies are employed as the basis for estimating the station coordinates and baseline solutions.

We have processed the observed data with the official final precise ephemerides distributed by International GNSS Service (IGS, Beutler et al., 1999). All available temporary measurements and continuous recordings of GPS data were processed with the Bernese GPS software (v.4.2) developed at the Astronomical Institute of the University of Berne (Hugentobler et al., 2001) to obtain the precise station coordinates. Four global IGS fiducial stations (TSKB, GUAM, TID2 and WUHN) on the international terrestrial reference frame (ITRF2000) (Altamimi et al., 2000) were used to determine the positions and velocities of four local permanent stations (CK01, S01R, KDNM, and KMNM) by minimizing common mode deviations from linear velocities. Then coordinates of 24 GPS stations in Ilan were calculated from the positions of four local stations whose coordinates were derived from the a priori positions and velocities. To the first approximation, assuming steady motion between stations during the four-year period, the scatter of data points was defined relative to a best-fit straight line on the plot of baseline components versus time (Dixon, 1991; Segall and Davis, 1997). The repeatability of baseline component (east, north, and vertical) or baseline length is obtained from the root-mean-square scatter about the linear trend.

Furthermore, we applied a method proposed by Shen et al. (1996) to estimate distribution of strain rate and rotation field according to the GPS velocity gradient tensor. This method simulates strain rates as continuous functions within the entire network and assumed every calculation point is a uniform strain rate field. In this study, the strain tensor of each calculation point is derived from the velocities of more than four observation points within a radius of $5 \mathrm{~km}$. 

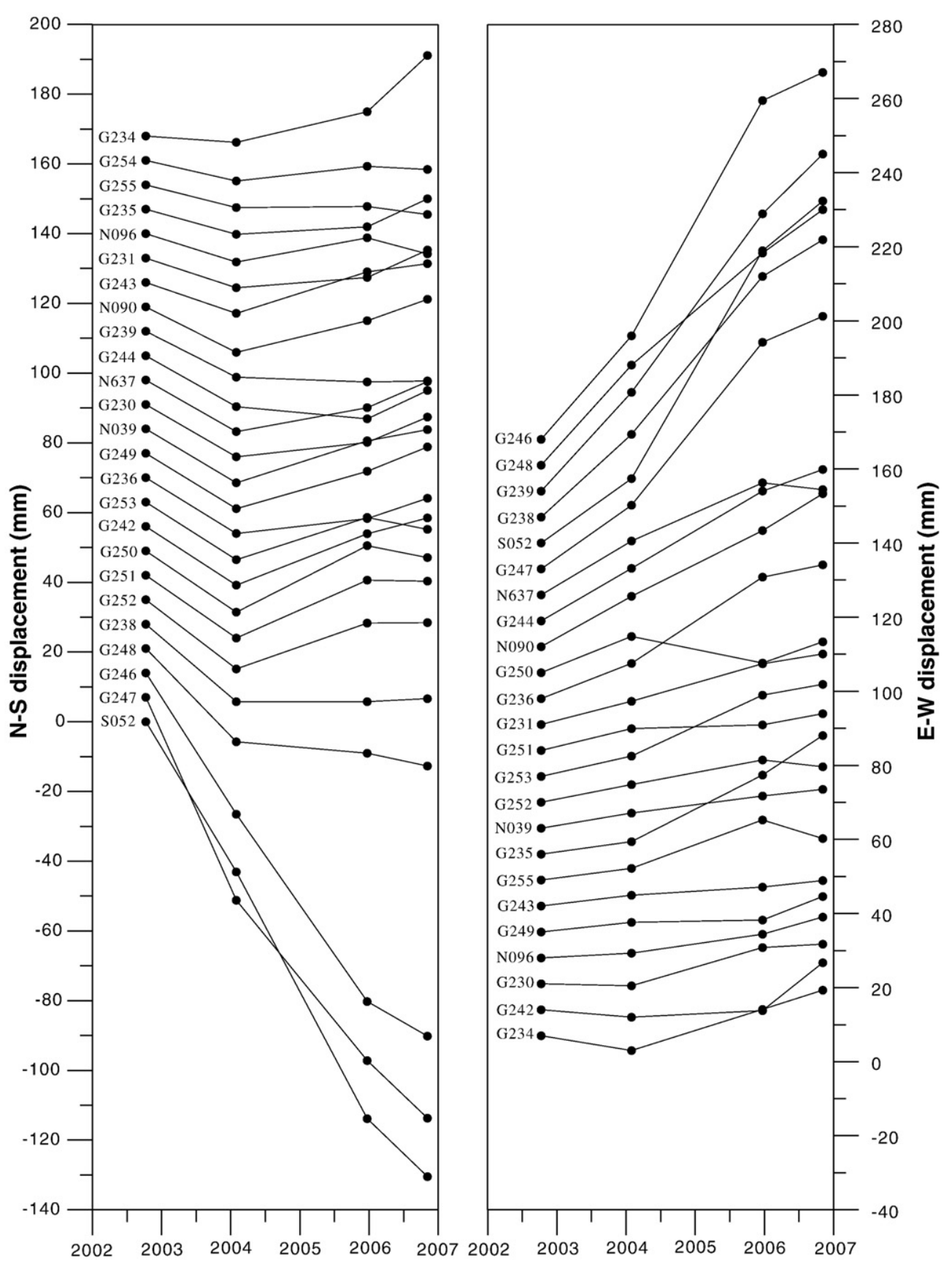

Fig. 5. The observed N-S and E-W displacement as a function of time from 2002 to 2006 for the benchmarks in study area.

\subsection{Velocity field of GPS stations in Ilan Plain}

We analyze the current deformation in Ilan Plain of northeastern Taiwan considered as the western extension of Okinawa Trough based on 34 GPS measurements from 2002 to 2005 (Table 1). The station velocities are between $1.9 \mathrm{~mm} / \mathrm{yr}$ and $43.0 \mathrm{~mm} / \mathrm{yr}$ in a direction between $17^{\circ}$ and $143^{\circ}$ relative to S01R located in Penghu island of the Penghu Archipelago. Based on the GPS measurements of E- and SE-Asia, North and South China are decoupled from Eurasia with a velocity of 4$13 \mathrm{~mm} / \mathrm{yr}$ moving eastward (Heki et al., 1999; Shen et al., 2000;
Michel et al., 2001). In addition, two stations in Kinmen and Matsu Islands on the western part of Taiwan Strait display a velocity of $12.3 \mathrm{~mm} / \mathrm{yr}$ and $11.8 \mathrm{~mm} / \mathrm{yr}$ relative to a VLBI station in Shanghai (Yu et al., 1999). Moreover, the station S01R is moving roughly eastward at a rate of $10.8 \mathrm{~mm} / \mathrm{yr}$ in the same frame. From the geodynamic point of view, this kinematic pattern indicates that the horizontal deformation within the Taiwan Strait and the foreland of Taiwan belt is negligible. Thus, the choice of station S01R as a kinematic reference is appropriate for the analysis of velocity field in northern Taiwan respect to the foreland of the Taiwan collision zone. 


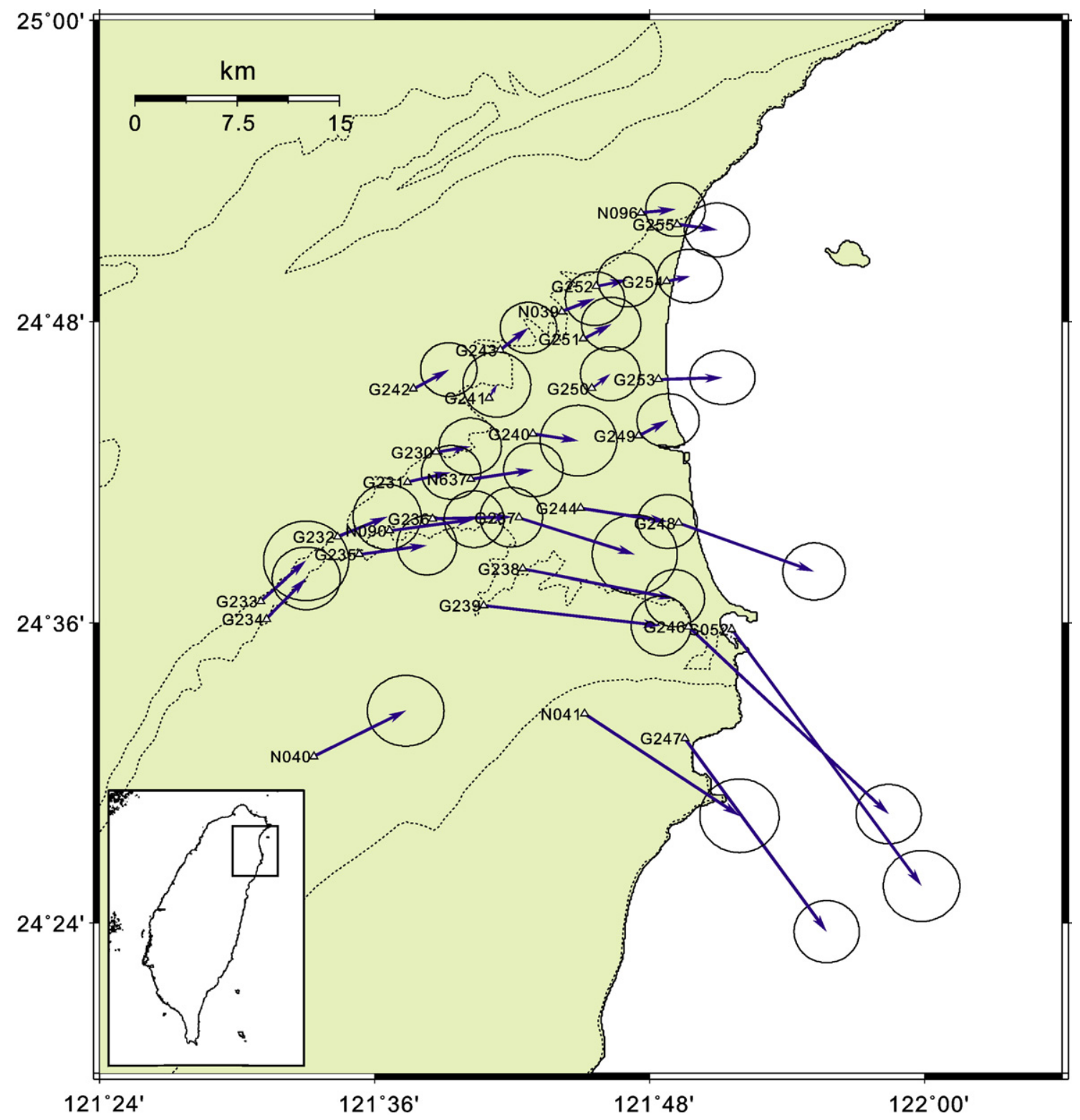

Fig. 6. Horizontal velocity field of GPS stations in Ilan Plain relative the station S01R located in Penghu island. Locality of S01R see Fig. 2. The 95\% confidence ellipse is shown at the tip of each velocity vector. Open triangles are the GPS stations.

The largest velocity is moving southeastward $\left(144^{\circ}\right)$ with a magnitude of $\sim 46 \mathrm{~mm} / \mathrm{yr}$, opposite to the direction of plate convergence. The station velocities at the northern margin of Ilan Plain are insignificant with a magnitude of $\sim 1.9 \mathrm{~mm} / \mathrm{yr}$ to $\sim 7.5 \mathrm{~mm} / \mathrm{yr}$ in a direction from $38^{\circ}$ to $90^{\circ}$. On the contrary, the station velocities increase approximately southward along the southern margin of Ilan Plain. The stations are moving roughly E-W with a magnitude of $\sim 5.8 \mathrm{~mm} / \mathrm{yr}$ to $\sim 21.8 \mathrm{~mm} / \mathrm{yr}$. Further southward, the stations velocities increase to a value of $\sim 45.6 \mathrm{~mm} / \mathrm{yr}$ in a direction of $144^{\circ}$. Angelier et al. (2007-this issue) suggest that the pattern of velocity vectors with a clockwise rotation around the Ilan Plain is approximately compatible with small circle and resembles a particle flow moving towards the southeast.
In combination with the velocity field of 34 GPS stations and its strain rate filed, we suggest that the lateral extrusion process towards mechanically weak domain adjacent Ryukyu subduction zone plays one of the major roles for the current deformation in the Ilan Plain area. In addition, the lateral extrusion should be facilitated by the opening of the Okinawa Trough. We conclude that northeast Taiwan is subjected to both the compressional force exerted by the indentation of Philippine Sea plate and the tensile force induced by trench retreat related to the suction force at the Ryukyu trench. Due to the interaction of two forces, the stress regime rapidly changes from pure compression in the Taiwan collision belt to transtensional regime near Ilan Plain and its offshore area. 
Table 1

Horizontal velocity field of GPS station in Ilan Plain

\begin{tabular}{|c|c|c|c|c|c|c|}
\hline Station & Lon. & Lat. & $\begin{array}{l}\mathrm{Vn} \\
(\mathrm{mm} / \mathrm{yr})\end{array}$ & $\begin{array}{l}\text { VE } \\
(\mathrm{mm} / \mathrm{yr})\end{array}$ & Azimuth & $\begin{array}{l}\text { Velocity } \\
(\mathrm{mm} / \mathrm{yr})\end{array}$ \\
\hline G230 & 121.644391 & 24.713212 & $0.77 \pm 1.60$ & $4.23 \pm 1.76$ & 79.68 & 4.30 \\
\hline G231 & 121.623632 & 24.693198 & $1.3 \pm 1.52$ & $5.44 \pm 1.68$ & 76.56 & 5.59 \\
\hline G232 & 121.572848 & 24.656962 & $2.78 \pm 1.84$ & $6.36 \pm 1.92$ & 66.39 & 6.94 \\
\hline G233 & 121.517268 & 24.614292 & $5.60 \pm 2.24$ & $5.74 \pm 2.40$ & 45.71 & 8.02 \\
\hline G234 & 121.521202 & 24.602519 & $5.61 \pm 1.76$ & $5.01 \pm 1.84$ & 41.77 & 7.52 \\
\hline G235 & 121.588628 & 24.645268 & $1.2 \pm 1.60$ & $8.8 \pm 1.68$ & 82.23 & 8.88 \\
\hline G236 & 121.641992 & 24.668826 & $0.01 \pm 1.68$ & $10.18 \pm 1.76$ & 89.94 & 10.18 \\
\hline G237 & 121.704861 & 24.669725 & $-5.13 \pm 3.68$ & $15.49 \pm 3.76$ & 108.32 & 16.32 \\
\hline G238 & 121.707770 & 24.635636 & $-4.02 \pm 1.60$ & $20.49 \pm 1.68$ & 101.10 & 20.88 \\
\hline G239 & 121.679106 & 24.611402 & $-2.75 \pm 1.68$ & $24.05 \pm 1.68$ & 96.52 & 24.21 \\
\hline G240 & 121.715073 & 24.725524 & $-1.03 \pm 2.88$ & $5.76 \pm 2.88$ & 100.14 & 5.85 \\
\hline G241 & 121.682998 & 24.749383 & $1.77 \pm 1.76$ & $0.54 \pm 1.92$ & 16.97 & 1.85 \\
\hline G242 & 121.627901 & 24.755245 & $2.61 \pm 1.44$ & $4.16 \pm 1.60$ & 57.90 & 4.91 \\
\hline G243 & 121.691316 & 24.781139 & $3.01 \pm 1.44$ & $3.27 \pm 1.60$ & 47.37 & 4.44 \\
\hline G244 & 121.749587 & 24.676015 & $-1.89 \pm 1.52$ & $11.51 \pm 1.68$ & 99.32 & 11.66 \\
\hline G246 & 121.827970 & 24.597398 & $-25.88 \pm 1.68$ & $27.2 \pm 1.84$ & 133.58 & 37.54 \\
\hline G247 & 121.825420 & 24.523143 & $-27.15 \pm 1.76$ & $19.21 \pm 1.84$ & 144.72 & 33.26 \\
\hline G248 & 121.821127 & 24.666138 & $-6.72 \pm 1.60$ & $18.16 \pm 1.76$ & 110.31 & 19.36 \\
\hline G249 & 121.791925 & 24.724095 & $2.09 \pm 1.52$ & $3.53 \pm 1.76$ & 59.37 & 4.10 \\
\hline $\mathrm{G} 250$ & 121.757754 & 24.755565 & $1.93 \pm 1.52$ & $2.06 \pm 1.68$ & 46.862 & 2.82 \\
\hline G251 & 121.751614 & 24.788565 & $1.98 \pm 1.52$ & $3.29 \pm 1.68$ & 58.96 & 3.84 \\
\hline G252 & 121.761141 & 24.823484 & $0.86 \pm 1.52$ & $3.74 \pm 1.68$ & 77.05 & 3.84 \\
\hline G253 & 121.806342 & 24.761659 & $0.2 \pm 1.52$ & $8.3 \pm 1.84$ & 88.62 & 8.30 \\
\hline G254 & 121.812131 & 24.826602 & $0.72 \pm 1.52$ & $2.71 \pm 1.84$ & 75.12 & 2.80 \\
\hline G255 & 121.819860 & 24.864646 & $-0.83 \pm 1.52$ & $4.99 \pm 1.84$ & 99.44 & 5.06 \\
\hline GS01 & 121.499937 & 24.983782 & $4.16 \pm 0.72$ & $1.21 \pm 0.96$ & 16.22 & 4.33 \\
\hline N039 & 121.736039 & 24.806710 & $1.75 \pm 1.44$ & $3.97 \pm 1.68$ & 66.21 & 4.34 \\
\hline N040 & 121.555749 & 24.511015 & $6.33 \pm 2.00$ & $12.19 \pm 2.16$ & 62.56 & 13.74 \\
\hline N041 & 121.752487 & 24.539410 & $-14.11 \pm 2.08$ & $20.90 \pm 2.24$ & 124.02 & 25.22 \\
\hline N090 & 121.610768 & 24.660981 & $1.6 \pm 1.60$ & $11.19 \pm 1.68$ & 81.86 & 11.30 \\
\hline N096 & 121.793531 & 24.872234 & $0.43 \pm 1.52$ & $4.22 \pm 1.68$ & 84.18 & 4.24 \\
\hline N637 & 121.669876 & 24.695336 & $1.27 \pm 1.52$ & $8.13 \pm 1.68$ & 81.12 & 8.23 \\
\hline S052 & 121.859685 & 24.595732 & $-34.34 \pm 1.68$ & $25.95 \pm 1.84$ & 142.92 & 43.04 \\
\hline YMSM & 121.565770 & 25.167517 & $2.39 \pm 0.88$ & $2.5 \pm 1.04$ & 46.29 & 3.46 \\
\hline
\end{tabular}

\subsection{Spatial variation of crustal strain of Ilan Plain}

The changes in baseline lengths from the repeated GPS surveys in the northern region of Taiwan are used to assess the spatial variation of the horizontal crustal strain over the region. Based on consideration of distribution of geodetic stations, the strain rate field is calculated by grids as shown in Fig. 7. It is assumed that, spatially, the crustal strain accumulates uniformly over each grid, and that the rate of strain accumulation is constant over the time period considered (2002-2006). The average principal strain rates for each of the 24 grids are given in Table 2. All uncertainties quoted are \pm 1 standard deviation. The strain rates are given in units of microstrain per year $\left(1 \mu\right.$ strain $\left.=10^{-6}\right)$. Positive values denote extension while negative values represent shortening or contraction. The most prominent feature of the strain distribution patterns in Ilan Plain are the remarkable extensional strain rates observed in central and southern flank of the Ilan Plain (Fig. 7). The largest extensional rate is found $\left(2.66 \mu\right.$ strain $/ \mathrm{yr}$ in $\left.147^{\circ}\right)$ with a shortening rate in the perpendicular direction $\left(1.28 \mu\right.$ strain $/ \mathrm{yr}$ in $\left.47^{\circ}\right)$, indicating transtensional deformation mode. Because this area is considered as a western extension of the Okinawa Trough (Liu, 1995), the extensional deformation is assumed to be related to extension in the Okinawa Trough (Letouzey and Kimura, 1985; Sibuet et al., 1987). In the northeastern flank of Ilan Plain, insignificant or minor deformations are observed. Overall the extensional rates in this area clearly increase from north to south. The extension directions in study area mostly trend $\mathrm{E}-\mathrm{W}$ to $\mathrm{NW}-\mathrm{SE}$ directions.

Significant extension rates of $0.43-1.52 \mu$ strain/yr in azimuths of $138.2^{\circ}-128.4^{\circ}$ are observed on the northern tip of the Central Range. The remarkable extension rates of $0.83-2.8 \mu$ strain $/ \mathrm{yr}$ in azimuths of $131.6^{\circ}-150^{\circ}$ are observed on the southern flank of the Ilan Plain. Furthermore, the extensional strain rates are also significant with a value of $0.94-1.5 \mu$ strain $/ \mathrm{yr}$ in azimuths of $36.4^{\circ}-145.5^{\circ} 1$. The extensional strain rates decrease to an insignificant values on the northeastern of the Ilan Plain.

A significant clockwise rotation of $1.17-1.45 \mu \mathrm{rad} / \mathrm{yr}$ occurred near the southern part of the Ilan Plain (Fig. 8). Liu (1995) also point out that the south edge of the trough had been 


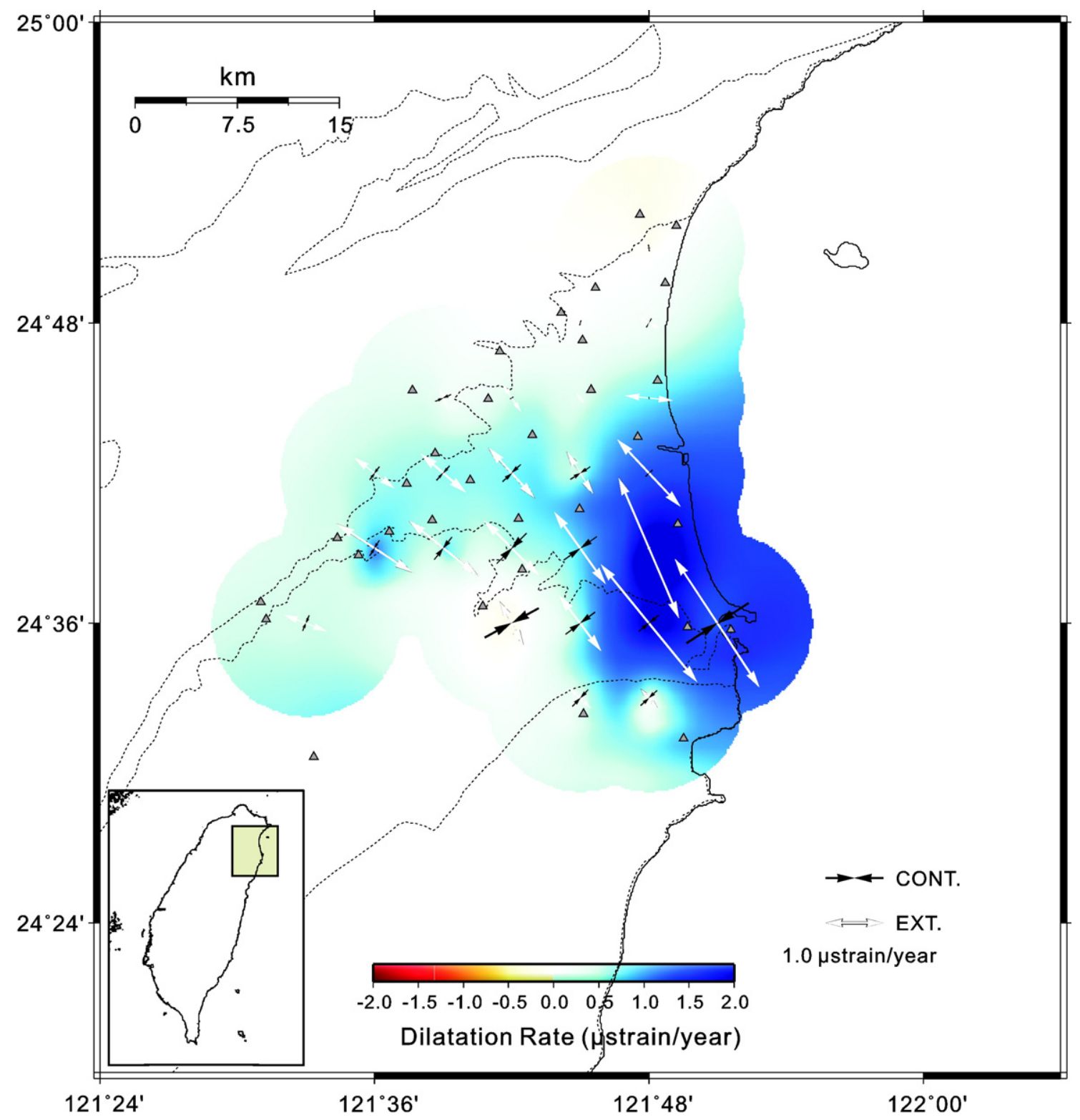

Fig. 7. Principal strain rates in the Ilan Plain. Convergent arrows denote contraction, whereas divergent arrows denote extension. Solid triangles represent the GPS stations.

opening with a $1.3 \mu \mathrm{rad} / \mathrm{yr}$ of clockwise opening. However, the rotation field changes to counterclockwise rotation with a rotation rate of about $0.26-0.69 \mu \mathrm{rad} / \mathrm{yr}$. This contrast of rotation may indicate an important structure corresponding the nearly E-W seismicity zone onland and offshore of southern Ilan Plain (Fig. 3).

\section{Discussion and conclusion}

The GPS results presented herein are the first detailed investigation of current deformation in the southwestern tip of the Okinawa Trough. In addition they provide a crucial interpretation of the observed stress and strain patterns for crustal rotations and extrusion (Figs. 4 and 6), in relation to the transition between collision and back-arc extension. The interaction between the Okinawa Trough opening and the collision of eastern Taiwan plays a crucial role in determining the regional stress patterns (Huchon et al., 1986; Hu et al., 1996, 2002). Teng (1996) and Teng et al. (2000) also suggested that the orogenic collapse of northern Taiwan is mainly triggered by the change of boundary forces induced by the change in vergence of subduction. According to such an interpretation, the westward-propagating collision combined with the flip of subduction resulted in major tectonic change in northern Taiwan. Especially, the continental margin of southern Ryukyu and northern Taiwan underwent a lithospheric thickening first, as induced by collision, and a lithospheric stretching second, as induced by trench suction (Viallon et al., 1986; Teng, 1996). 
Table 2

Strain rate, rotation rate and dilation in study area

\begin{tabular}{|c|c|c|c|c|c|c|}
\hline Lon. & Lat. & EPS1 & EPS2 & Theta & Rotation & Dilatation \\
\hline$\left({ }^{\circ}\right)$ & $\left({ }^{\circ}\right)$ & ( $\mu$ strain/yr) & ( $\mu$ strain/yr) & & ( $\mu \mathrm{rad} / \mathrm{yr})$ & ( $\mu$ strain/yr) \\
\hline 121.75 & 24.55 & 0.52 & -0.40 & -46.79 & 1.17 & 0.12 \\
\hline 121.80 & 24.55 & 0.43 & -0.39 & -41.82 & 1.35 & 0.04 \\
\hline 121.55 & 24.60 & 0.80 & -0.29 & -68.82 & 0.09 & 0.51 \\
\hline 121.70 & 24.60 & 0.84 & -1.06 & -28.74 & 0.00 & -0.22 \\
\hline 121.75 & 24.60 & 1.21 & -0.63 & -36.97 & 0.49 & 0.58 \\
\hline 121.80 & 24.60 & 2.63 & -0.45 & -39.27 & 1.11 & 2.18 \\
\hline 121.85 & 24.60 & 2.66 & -1.28 & -33.32 & 1.45 & 1.38 \\
\hline 121.60 & 24.65 & 1.54 & -0.31 & -57.13 & -0.46 & 1.23 \\
\hline 121.65 & 24.65 & 1.52 & -0.50 & -51.62 & -0.53 & 1.02 \\
\hline 121.70 & 24.65 & 1.35 & -0.74 & -45.06 & -0.64 & 0.61 \\
\hline 121.75 & 24.65 & 1.54 & -0.70 & -35.49 & -0.69 & 0.84 \\
\hline 121.80 & 24.65 & 2.65 & 0.07 & -23.24 & -0.39 & 2.72 \\
\hline 121.60 & 24.70 & 0.87 & -0.28 & -52.41 & -0.26 & 0.59 \\
\hline 121.65 & 24.70 & 1.03 & -0.34 & -49.21 & -0.36 & 0.70 \\
\hline 121.70 & 24.70 & 1.19 & -0.44 & -42.51 & -0.51 & 0.75 \\
\hline 121.75 & 24.70 & 0.86 & -0.40 & -32.13 & -0.66 & 0.46 \\
\hline 121.80 & 24.70 & 1.60 & -0.16 & -43.19 & -0.46 & 1.40 \\
\hline 121.65 & 24.75 & 0.38 & -0.30 & -22.61 & -0.11 & 0.08 \\
\hline 121.70 & 24.75 & 0.57 & -0.07 & -34.19 & -0.13 & 0.50 \\
\hline 121.75 & 24.75 & 0.24 & 0.09 & -38.40 & -0.11 & 0.33 \\
\hline 121.80 & 24.75 & 0.83 & -0.04 & -84.05 & 0.15 & 0.79 \\
\hline 121.75 & 24.80 & 0.12 & -0.09 & -72.26 & 0.10 & 0.03 \\
\hline 121.80 & 24.80 & 0.39 & -0.16 & -62.40 & -0.04 & 0.23 \\
\hline 121.80 & 24.85 & -0.04 & -0.12 & 82.42 & 0.18 & -0.16 \\
\hline
\end{tabular}

Based on numerical simulations, $\mathrm{Hu}$ et al. $(1996,2002)$ proposed that a transitional zone with transtensional and transpressional regimes occurred in northern Taiwan. The regional models demonstrated that the maximum tension in the Okinawa Trough area rotates counterclockwise from N-S to NW-SE, with magnitudes that decrease rapidly in approaching northeast Taiwan (Fig. 4). Angelier et al. (2007-this issue) also point out that three main subnets of normal-type earthquake coexist, compatible with NW-SE, N-S and $\mathrm{E}-\mathrm{W}$ trends of extension. Base on the inversion of strike-slip type earthquake, the NW$\mathrm{SE}$ trending minimum stress axis is also in agreement with the extension revealed by one group of normal type earthquake. These two regimes of normal type and strike-slip type are due to the permutation between maximum and intermediate principal stresses which is a common phenomenon in brittle tectonics (Hu and Angelier, 2004). Our results of strain rate field also show the NW-SE dominant extension rate in Ilan Plain (Fig. 7). In the Ilan Plain area, the current deformation is characterized by elongation trending NW-SE in central and southern flank of the Plain. In general, the elongation is minor close to the mountain and rapidly increases towards the south and southeast (Fig. 7).

Based on the six measurements of repeated precise leveling along the coastal area of Ilan Plain since 1985 (Liu, 1995), the whole area suffers from serious subsidence nearly in a V-shaped depression. The seismic profile of the basement of Ilan Plain also shows an asymmetric V-shaped valley (Chiang, 1976). Thus, the main stream of the river follows the lowest tip of the $\mathrm{V}$-shaped sinking basin. The tilting on both sides is almost equal and the averaged tilting rate is about $1.2 \mu \mathrm{rad} / \mathrm{yr}$ over the period of study. The crust tilted gradually eastward, the current tilting rate is $0.44 \mu \mathrm{rad} / \mathrm{yr}$ (Liu, 1995). In addition, the south edge of the Ilan Plain rotated clockwise for about $1.3 \mu \mathrm{rad} / \mathrm{yr}$. This observation suggested that a southward propagation of the tip of the opening is $126 \mathrm{~mm} / \mathrm{yr}$. Our results of strain and rotation rate field also indicate that more extension occurred in the south edge of the Ilan Plain (Figs. 7 and 8).

Northeast off Taiwan, the Okinawa Trough area is dominated by extensional tectonics (Letouzey and Kimura, 1986; Sibuet et al., 1987) as an effect of the suction force related to the Ryukyu trench retreat. The extensional regime present in northeastern Taiwan, especially for the $\mathrm{N}-\mathrm{S}$ or $\mathrm{E}-\mathrm{W}$ extension near the Ilan Plain is the westernmost compression of the slab-related backarc extension. Hu et al. (1996, 2002) have confirmed that extension in the Ryukyu arc and the western Okinawa Trough cannot be explained by lateral extrusion solely, as a simple consequence of the Taiwan collision. Wallace et al. (2005) also pointed out that the change from collision to subduction exerts a torque on the upper-plate microplate, resulting in a rapid rotation of upper-plate microplate. In addition, this rotation often facilitates the back-arc rifting. Extension of the Okinawa Trough is being advanced by the collision of Taiwan and rotation of the junction (Nakamura, 2004). Initiation of the rifting of the southern Okinawa Trough was suggested to be around 1.62.0 Ma (Park et al., 1998; Hsu, 2001). The westward migration of rifting arc-continent collision would result in the retreat of the subducted South China Sea slab beneath Taiwan and generate edge flow (Lin et al., 2004a,b; Nakamura, 2004). Nakamura (2004) suggested that the edge mantle flow would induce the deformation of the Philippine Sea slab beneath the Ryukyu Arc and the southward migration of the Ryukyu Trench. Thus, the southern Ryukyu Trough is generated by the rotation and migration of the junction between Taiwan and Ryukyu Arc.

We point out that the suction force related to the southward retreat of the Ryukyu subduction zone plays a major role. The westward migration of the Okinawa Trough seems to be the reason for increasing intensity of extension with time in northern Taiwan. The interaction discussed above can explain the spatial clockwise rotation of stress axes from NW-SE to nearly $\mathrm{N}-\mathrm{S}$ compression, then progressively to $\mathrm{E}-\mathrm{W}$ extension and finally to $\mathrm{N}-\mathrm{S}$ extension. The previous numerical models (Hu et al., 1996; 2002) predicted that the maximum tension in the Okinawa Trough rotates significantly from $\mathrm{N}-\mathrm{S}$ to $\mathrm{NW}-\mathrm{SE}$, with magnitudes that decrease rapidly towards northeast Taiwan (Fig. 4). We conclude that current deformation in Ilan area is subjected to both the influence of the compressional force exerted by the indentation of Philippine Sea plate and the tensile force induced by trench retreat related to the suction force at the Ryukyu trench. Due to the interaction of two forces, the stress-strain pattern is consistent with the transtensional regime near Ilan Plain and its offshore area.

\section{Acknowledgments}

We are grateful to Editors Benoit Deffontaines, Shu-Kun Hsu, and two anonymous reviewers for their constructive comments and suggestions. We benefit from the discussion with L.-C. Kuo and H.-Y. Chen. This research was financially supported by the National Science Council of the Republic of China under grant 


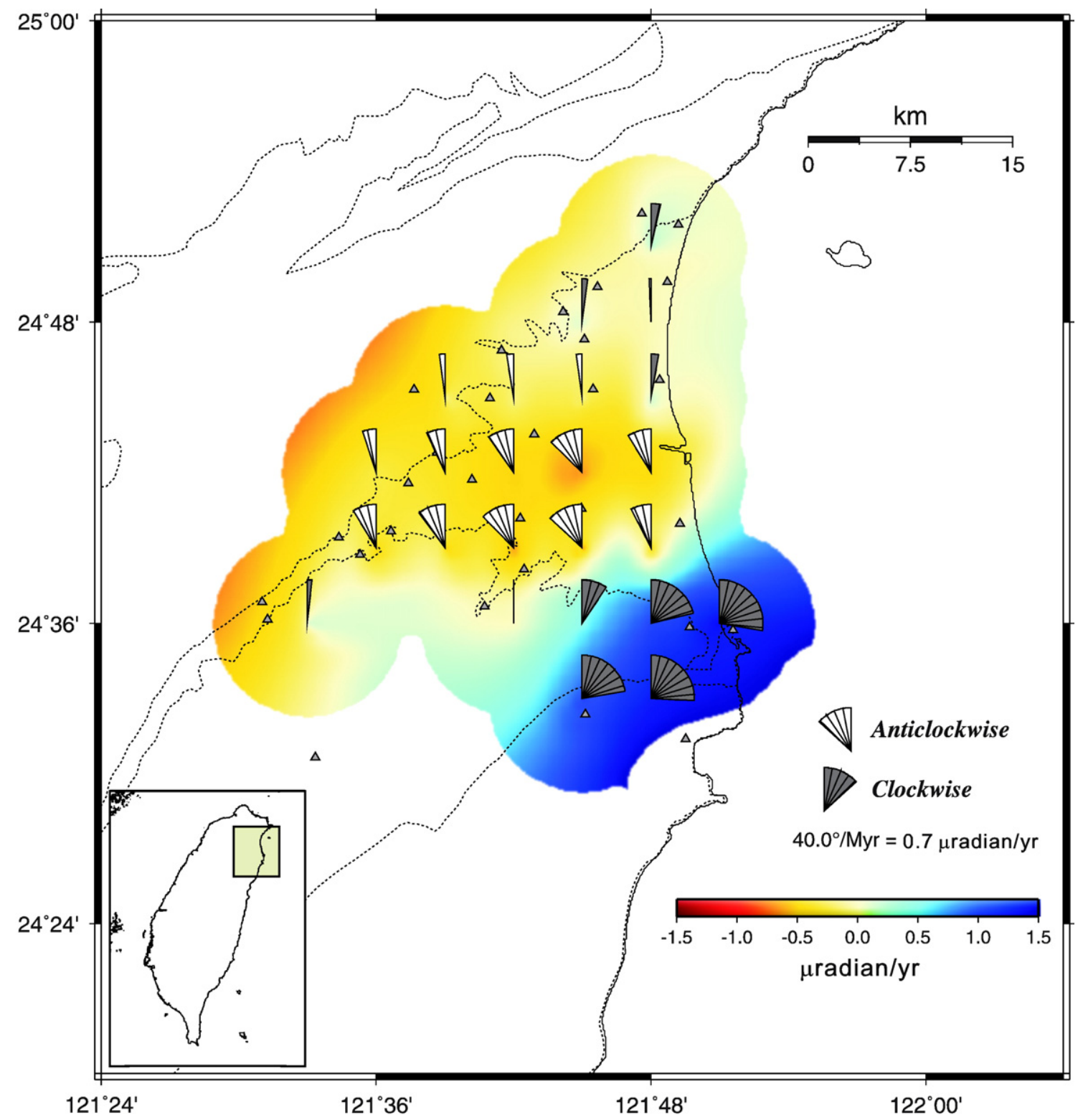

Fig. 8. Rotation rate field in study area. Solid triangles represent the GPS stations.

NSC93-2116-M-002-008 and Central Geological Survey, MOEA. This research was supported by the Taiwan Earthquake Research Center (TEC). The TEC contribution number for this article is 00025 . Some figures are generated by the GMT software written by Paul Wessel and Walter H. F. Smith (1998).

\section{References}

Altamimi, Z., Sillard, P., Boucher, C., 2002. ITRF2000: a new release of the International Terrestrial Reference Frame for earth science applications. J. Geophys. Res. 107, 2214. doi:10.1029/2001JB000561.

Angelier, J., 1990. Foreword, special issue "Geodynamic Evolution of the Eastern Eurasian Margin”. Tectonophysics 183, VII-X.

Angelier, J., Bergerat, F., Chu, H.-T., Lee, T.-Q., 1990. Tectonic analysis and the evolution of a curved collision belt: the Hsüehshan Range, northern Taiwan. Tectonophysics 183, 77-96.

Angelier, J., Chang, T.-Y., Hu, J.-C., Chang, C.-P., Siame, L., Lee, J.-C., Deffontaines, B., Chu, H.-T., Lu, C.-Y., 2007. Does extrusion occurs at both tips of the Taiwan collision belt? Insights from active deformation studies in the Ilan Plain and Pingtung Plain regions. Tectonophysics, this issue.

Beutler, G., Rothacher, M., Schaer, S., Springer, T.A., Kouba, J., Neilan, R.E., 1999. The International GPS Service (IGS): an interdisciplinary service in support of Earth Sciences. Adv. Space Res. 23 (4), 631-635.

Chiang, S.-C., 1976. Seismic prospecting in the Ilan Plain. Mineral Technology 215-221 (in Chinese).

Dixon, T.H., 1991. An introduction to the Global Positioning System and some geological applications. Rev. Geophys. 29, 249-276.

Heki, K., Miyazaki, S., Takahashi, H., Kasahara, M., Kimata, F., Miura, S., Vasilenko, N.F., Ivashchenko, A., An, K.D., 1999. The Amurian Plate motion and current plate kinematics in eastern Asia. J. Geophys. Res. 104, 29147-29156.

Ho, C.-S., 1986. A synthesis of the geological evolution of Taiwan. Tectonophysics $125,1-16$.

Hsu, S.-K., 2001. Lithospheric structure, buoyancy and coupling across the southernmost Ryukyu subduction zone: an example of decreasing plate coupling. Earth Planet. Sci. Lett. 186, 471-478.

Hu, J.-C., Angelier, J., Lee, J.-C., Chu, H.-T., Byrne, D., 1996. Kinematics of convergence, deformation and stress distribution in the Taiwan 
collision area: 2-D finite-element numerical modeling. Tectonophysics 255 , $243-268$.

Hu, J.-C., Yu, S.-B., Chu, H.-T., Angelier, J., 2002. Transition tectonics of northern Taiwan induced by convergence and trench retreat. In: Byrne, T.B., Liu, C.-S. (Eds.), Geology and Geophysics of an Arc-Continent Collision, Taiwan. Boulder, Colorado. Boulder, Colorado, Geol. Soc. Am. Special Paper, 358, pp. 147-160.

Hu, J.-C., Angelier, J., 2004. Stress permutations: three-dimensional distinct element analysis accounts for a common phenomenon in brittle tectonics. J. Geophy. Res. 109, B09403. doi:10.1029/2003JB002616.

Huchon, P., Barrier, E., De Bremaecker, J.-C., Angelier, J., 1986. Collision and stress trajectories in Taiwan: a finite element model. Tectonophysics 125, 179-191.

Hugentobler, U., Schaer, S., Fridez, P., 2001. Bernese GPS software, Version 4.2. Astronomical Institute, University of Berne. $515 \mathrm{pp}$.

Kao, H., Chen, W.-P., 1991. Earthquakes along the Ryukyu-Kyushu arc: strain segmentation, lateral compression, and the thermomechanical state of the plate interface. J. Geophys. Res. 96, 21443-21485.

Kao, H., Shen, S.-J., Ma, K.-F., 1998. Transition from oblique subduction to collision: earthquakes in the southernmost Ryukyu arc-Taiwan Region. J. Geophys. Res. 103, 7211-7229.

Kao, H., Jian, P.-R., 2001. Seismogenic patterns in the Taiwan region: insights from source parameter inversion of BATS data. Tectonophysics 333, 179-198.

Lallemand, S., Liu, C.-S., Dominguez, S., Schnürle, P., Malavieille, J., ACT Scientific Crew, 1999. Trench-parallel stretching and folding of forearc basins and lateral migration of the accretionary wedge in the southern Ryukyu: a case of strain partition caused by oblique convergence. Tectonics $18,231-247$.

Lee, C.-T., Wang, Y., 1988. Quaternary stress changes in northern Taiwan and their tectonic implication. Proc. Geol. Soc. China 31, 154-168.

Letouzey, J., Kimura, M., 1985. The Okinawa Trough genesis, structure and evolution of a back-arc basin developed in a continent. Mar. Pet. Geol. 2, $111-130$.

Letouzey, J., Kimura, M., 1986. The Okinawa Trough: genesis of a back-arc basin developing along a continental margin. Tectonophysics 125, 209-230.

Lin, J.-Y., Hsu, S.-K., Sibuet, J.-C., 2004a. Melting features along the Ryukyu slab tear, beneath the southwestern Okinawa Trough. Geophys. Res. Lett. 31, L19607. doi:10.1029/2004GL020862.

Lin, J.-Y., Hsu, S.-K., Sibuet, J.-C., 2004b. Melting features along the western Ryukyu slab edge (northeast Taiwan): tomographic evidence. J. Geophys. Res. 109, B12402. doi:10.1029/2004JB003260.

Liu, C.-C., 1995. The Ilan Plain and the southwestward extending Okinawa Trough. J. Geol. Soc. China 38, 229-242.

Lu, C.-Y., Angelier, J., Chu, H.-T., Lee, J.-C., 1995. Contractional, transcurrent, rotational and extensional tectonics: examples from Northern Taiwan. Tectonophysics 125, 129-146.

Malavieille, J., Lallemand, S.E., Dominquez, S., Deschamps, A., Lu, C.-Y., Liu, C.-S., Schnürle, P., 2002. Arc-continent collision in Taiwan: new marine observations and tectonic evolution. In: Byrne, T.B., Liu, C.-S. (Eds.), Geology and Geophysics of an Arc-Continent Collision, Taiwan. Boulder, Colorado, Geol. Soc. Am. Special Paper, 358, pp. 187-211.

Michel, G.W., Yu, Y.Q., Zhu, S.Y., Reigber, C., Becker, M., Reinhart, E., Simons, W., Ambrosius, B., Vigny, C., Chamot-Rooke, N., Le Pichon, X., Morgan, P., Matheussen, S., 2001. Crustal motion and block behaviour in SE-Asia from GPS measurements. Earth Planet. Sci. Lett. 187 (3-4), 239-244.
Nakamura, M., 2004. Crustal deformation in the central and southern Ryukyu Arc estimated from GPS data. Earth Planet. Sci. Lett. 217, 389-398.

Nishimura, S., Hashimoto, M., Ando, M., 2004. A rigid block rotation model for GPS derived velocity field along the Ryukyu arc. Phys. Earth. Planet. Interiors $142,185-203$

Park, J.O., Tokkuyama, H., Shinohara, M., Suyehiro, K., Taira, A., 1998. Seismic record of tectonic evolution and backarc rifting in the southern Ryukyu island arc system. Tectonophysics 294, 21-42.

Sato, T., Koresawa, S., Shiozu, Y., Kusano, F., Uechi, S., Nagaoka, O., Kasahara, J., 1994. Microseismicity of back-arc rifting in the middle Okinawa Trough. Geophys. Res. Lett. 21, 13-16.

Segall, P., Davis, J.L., 1997. GPS applications for geodynamics and earthquake studies. Annu. Rev. Earth Planet. Sci. 25, 301-336.

Shen, Z.K., Jackson, D.D., Ge, B.X., 1996. Crustal deformation across and beyond the Los Angeles basin from geodetic measurements. J Geophys Res. 101, 27957-27980.

Shen, Z.K., Zhao, C., Yin, A., Li, Y., Jackson, D.D., Fang, P., Dong, D., 2000. Contemporary crustal deformation in east Asia constrained by Global Positioning System measurements. J Geophys. Res. 105, 5721-5734.

Sibuet, J.-C., Letouzey, J., Barbier, F., Charvet, J., Foucher, J.P., Hilde, Thomas W.C., Kimura, M., Chiao, L.-Y., Marsset, B., Muller, C., Stephan, J.F., 1987. Back-arc extension in the Okinawa trough. J. Geophys. Res. 92, 14041-14063.

Sibuet, J.-C., Deffontaines, B., Hsu, S.-K., Thareau, N., Formal, J.-P., Liu, C.-S., 1998. Okinawa trough backarc basin: early tectonic and magmatic evolution. J. Geophys. Res. 103, 30245-30267.

Suppe, J., 1984. Kinematics of arc-continent collision, flipping of subduction and back-arc spreading near Taiwan. Geol. Soc. China 6, 21-33.

Teng, L.S., 1990. Geotectonic evolution of late Cenozoic arc-continent collision in Taiwan. Tectonophysics 183, 57-76.

Teng, L.S., 1992. Geotectonic evolution of Tertiary continental margin basins of Taiwan. Pet. Geol. Taiwan 27, 1-19.

Teng, L.S., 1996. Extensional collapse of the northern Taiwan mountain belt. Geology 24, 949-952.

Teng, L.S., Lee, C.-T., Tsai, Y.-B., Hsiao, L.-Y., 2000. Slab breakoff as a mechanism for flipping of subduction polarity in Taiwan. Geology 28, 155-158.

Tsai, Y.-B., 1986. Seismotectonics of Taiwan. Tectonophysics 125, 17-37.

Viallon, C., Huchon, P., Barrier, E., 1986. Opening of the Okinawa basin and collision in Taiwan: a retreating trench model with lateral anchoring. Earth Planet. Sci. Lett. 80, 145-155.

Wallace, L.M., McCaffrey, R., Beavan, J., Ellis, S., 2005. Rapid microplate rotations and backarc rifting at the transition between collision and subduction. Geology 33(11), 857-860. doi:10.1130/G21834.1.

Wessel, P., Smith, W.H.F., 1998. New, improved version of the Generic Mapping Tools Released. EOS Trans. AGU 79, 579

Yeh, Y.-H., Barrier, E.C.-H., Lin, C.-H., Angelier, J., 1991. Stress tensor analysis in the Taiwan area from focal mechanisms of earthquakes. Tectonophysics 200, 267-280.

Yu, S.-B., Chen, H.-Y., Kuo, L.-C., 1997. Velocity field of GPS Stations in the Taiwan area. Tectonophysics 274, 41-59.

Yu, S.-B., Kuo, L.-C., Punongbayan, R.S., Ramos, E.G., 1999. GPS observation of crustal deformation in the Taiwan-Luzon region, Geophys. Res. Lett. 26, 923-926.

Yu, S.-B., Kuo, L.-C., 2001. Present-day crustal motion along the Longitudinal Valley Fault, eastern Taiwan. Tectonophysics 333, 199-217. 